HOW

Volume 28, Number 3, pages 93 - 104

https://doi.org/10.19183/how.28.3.674

\title{
Comprehending Interculturality and its Future Directions in English Language Teaching and Teacher Education in the Colombian Context
}

\author{
Comprendiendo la Interculturalidad y sus Direcciones \\ Futuras en la Enseñanza del Inglés y la Formación Docente \\ en el Contexto Colombiano
}

\section{Bertha Ramos-Holguín ${ }^{1}$}

\begin{abstract}
Interculturality has to do with the personal relational aspects of caring about the other. In this sense, interculturality confronts and challenges untruths and stereotypes that deny the existence of diversity. This article aims to provide a comprehensive view of what interculturality means, as well as to contribute to current and future trends in the field of English language teaching and teacher education in Colombia. I present examples of intercultural practices as possibilities to understand and explore interculturality in ELT, and I share a review of studies that have undertaken this complex conception of interculturality.
\end{abstract}

Keywords: decoloniality, English language teaching, interculturality, intercultural practices

\section{Resumen}

La interculturalidad tiene que ver con los aspectos relacionales del cuidado hacia el otro. En este sentido, la interculturalidad confronta y reta las falsedades y los estereotipos que niegan la existencia de la diversidad. Este artículo busca proveer una mirada comprensiva de lo que significa la intercul-

She holds a Ph.D. in Education Sciences from Universidad Pedagógica y Tecnológica de Colombia (UPTC) and an M.A. in Applied Linguistics to the Teaching of English as a Foreign Language from Universidad Distrital Francisco José de Caldas. She is a professor in the School of Languages at UPTC and she is the leader of the research group TONGUE

bertha.ramos@uptc.edu.co

ORCID ID: https://orcid.org/0000-0003-4468-1402

Received: May 19th, 2021. Accepted: June 15th, 2021.

This article is licensed under a Creative Commons Attribution-Non-Commercial-No-Derivatives 4.0 International License. License Deed can be consulted at https://creativecommons.org/licenses/by-nc-nd/4.0. 
turalidad y así, intenta contribuir a las direcciones actuales y futuras en relación con la enseñanza del inglés y la formación docente en el contexto colombiano. Se presentan algunas prácticas interculturales como posibilidades para entender y explorar la interculturalidad en la enseñanza del inglés como lengua extranjera y se presenta algunos estudios que han considerado esta concepción compleja de interculturalidad.

Palabras clave: interculturalidad, practicas interculturales, decolonialidad, diversidad, enseñanza del inglés

\section{Introduction}

In this article, my goal is to conceptualize interculturality from a comprehensive perspective. Interculturality is linked to territories, which is why I argue that the concept should be pluralized. Therefore, we are called to think about interculturalities. This concept also encompasses the need to care about others. Soto (2013) suggested that caring is a genuine love for another that entails "recognizing their talents, their identities and their needs. It also means demonstrating an interest in their families and their communities by interacting frequently with them, attending community events, and becoming in some sense a member of those communities" (p. 35).

I also want to recognize Walsh's (2009) idea that interculturality should be addressed from a critical stance, in which Western ideologies and their systems of oppression, domination, social exclusion, and control are questioned. Based on an idea of critical interculturalities, English language teaching and teacher education in Colombia should focus on promoting spaces that acknowledge intercultural practices that aim at respect and embrace diversity.

\section{Interculturality}

From a critical standpoint, interculturality is more interested in achieving coexistence based on mutual respect and equality between different social groups. In that sense, critical interculturality takes a step forward from merely tolerating the other culture. Therefore, interculturality "aims at respect and coexistence between cultures, which allows not only an equal relationship but also mutual learning and enrichment" (Cruz, 2013, p. 55).

A review of Walsh (2009) suggests that interculturality could be approached from three different perspectives: relational, functional, and critical. Relational interculturality accounts for contact between diverse cultures. In this sense, interculturality relates to any kind of interaction between cultural groups. According to Granados-Beltrán (2016) "this view of interculturality remains oblivious to societal structures that maintain inequality within these relations" (p. 175). 
Functional interculturality refers to multicultural-neoliberal discourses, and it is compatible with Western logic. This kind of interculturality promotes cultural encounters based on tolerance. Functional interculturality accommodates cultural plurality according to the values of liberalism, tolerance, and coexistence between cultures. In fact, functional interculturality "denies the rational character of all forms of knowledge that are not based on their epistemological principles and on their methodological rules" (De Sousa Santos, 2010, p. 21).

The third perspective, critical interculturality, refers to "a critical construction of and by people that have suffered a history of subjugation and subordination" (Walsh, 2009, p. 9). Critical interculturality relates to and questions the geopolitics of colonized people. It focuses on diversity and difference, as well as on the way these concepts have been constructed throughout history. Critical interculturality aims at making several types of knowledge visible. In this sense, knowledge can also be pluralized to its form "knowledges" to account for a diversity of thoughts. This is, according to De Sousa Santos' (2010) categorization, an endeavour that promotes the ecology of wisdoms because it is based on the recognition of pluralities and diverse knowledge. Critical interculturality problematizes the notion that unique knowledges and truths coexist and are characterized by the power relationships they were built upon.

Therefore, critical interculturality takes into account that wisdom and knowledge are not singular. On the contrary, different types of knowledge can be relevant to each individual. As a result, critical interculturality is an ethical-political project (Tubino, 2005), whose goal is re-existence and coexistence with others in society in order to transform existing social structures through dialogue.

All in all, I refer to interculturality from a critical perspective in this article. In this sense, interculturality accounts for cultural differences that are shaped by historical processes. Interculturality implies learning from the other as a possibility to grow as a human being. Furthermore, interculturality does not imply harmony; rather, conflict and negotiation can arise as part of the process. Interculturality is perceived as a situated construction, which attempts to comprehend and, eventually, transform realities. It also fights against exotic and primitive ideas during intercultural encounters that might occur when others are seen as "strange" people with "interesting" lives worthy of being observed (this is discussed in more depth in Ramos, 2019).

Critical interculturality also emphasizes the need for "listening, dialogue, a common pursuit, active methodologies, and participation and cooperation techniques" (Besalú, 2002, p. 38). When we listen to and dialogue with the other, critical interculturality helps problematize unequal power relationships, inequities, marginalization of ethnic groups, 
racialization, adultcentrism, female subjugation, heterosexism, and political and religious alternatives (Albán, 2008).

Interculturality is dynamic given its constant evolution and negotiation. It recognizes that subjects should establish processes in which they act autonomously and demonstrate their capacities and abilities to develop their own knowledge as suggested in RamosHolguín \& Peñaloza (2019). That knowledge is conversant with the Territory that the subject belongs to. As such, interculturality is a process where we have to read ourselves and our context from a critical perspective. In this sense, we must learn to first read, at least partially, the processes of subjectivation that have been historically constructed in diverse Territories. I have decided to capitalize the " $\mathrm{T}$ " in Territories because I understand that Territory refers to not just a piece of land but signifies the histories and the identities of people who inhabit the land.

As mentioned above, interculturality is linked to the concept of Territories. Territories encompass symbolic, cultural, and economic factors. Mazurek (2015) mentioned that "territories are the portion of the terrestrial surface area appropriated by a social group to ensure that they can reproduce and meet their vital needs" (p. 7). In this sense, territories are much more than a piece of land. In fact, a Territory can be a community, an institution, and even a body.

Territories have a historical construction and are part of people's identities. People have a special connection with the land they inhabit; they co-construct their own identities based on their experiences within their Territories. People are tied to their own Territories, which makes Territories part of who we are as human beings. Moreover, Territories are diverse, a reality which supports the notion of interculturalities given that intercultural practices differ based on the Territories in which they take place.

Under the previous idea of interculturalities, the concept of Territories opposes a technical definition in which land is determined by its extension and agricultural possibilities. Rather, Territories account for the social behaviors of the community that inhabits it. Territories are not geographical spaces but social ones, and it is in these socially diverse spaces that intercultural practices come into play.

\section{Intercultural Practices}

Intercultural practices are expressions in which interculturality can be perceived, and they connect to a person's academic and personal lived experiences. Rodriguez, Aristizábal, Achinte, Pérez, Lozada, Guzmán, and Gaviria (2016) developed a research study related to the intercultural experiences of co-existence in four schools located in El Mazizo, Colombia. The authors accounted for intercultural practices related to artistic manifestations, relationships 
with others, territories as spaces to construct relationships, and ecology of knowledges. They described the intercultural practices as a rainbow because each institution was different. They also suggested that intercultural practices could be considered from a decolonial perspective as they make marginalized and excluded societies visible.

As such, intercultural practices attempt to contribute to the collective Project known as the decolonial turn (Maldonado-Torres, 2007). The decolonial turn looks to develop a geopolitical perspective in regard to knowledge and specific contexts. Additionally, the decolonial turn echoes the voices of those subjects who have been historically silent.

To provide an example, an indigenous group that uses simple tools, heats their homes with wood fuel, and are horticulturists may be considered primitive or "underdeveloped" from a colonial perspective. However, questions about this assumption merge, such as who says they are underdeveloped? What model of a "developed" culture are we using? Do all cultures have to seek this definition of development?

In terms of the example above, development may be widely accepted as the use of more energy per capita. However, this is a notion that is often linked to an idea of progress. Progress is almost always seen as something desirable by "normal" members of societies. For instance, a person with Western ideologies may think it is better to die of old age if he or she has access to more technology to live longer. Thus, he or she will see this technology as progress. On the other hand, a person who is unaware of his or her age -as is the case with many indigenous groups who measure age differently- may not share the same ideas on progress. Rather, he or she sees life as a passing of stages: child, young adult, adult, and elder. Being an "elder" may come at ages 40 to 45 , while death is around age 45 to 50 . Additionally, death might not be a tragic event since the person has lived through all of the stages of his or her life in company of his or her children and grandchildren. In other cases, dying of old age may seem undesirable if one is unable to take care of one's self. As mentioned before, the concept of death varies from person to person.

We may assume that everyone wants to die of old age; nonetheless, concepts like death, old age, happiness, and others vary from person to person. Therefore, a singular concept of progress from a Western ideological point of view, as something desired by all human beings, is not necessarily true for all groups. That is why the acknowledgement of diverse intercultural practices might guide us to think and act from a decolonial perspective.

Examples of intercultural practices that might help us, as EFL teachers, act on the decolonial turn include the following: arts, crafts and cultural manifestations; permanent dialogue in pedagogical environments; negotiation of pedagogical agendas; relationships with territories, traditional lands, and nature; and ecology of knowledges. 


\section{Arts, Crafts, and Cultural Manifestations}

Arts, crafts, and cultural manifestations provide an opportunity to explore and comprehend culture as a field of struggle. From an intercultural perspective, arts, crafts, and cultural manifestations give teachers the possibility to wonder about cultural diversity. Interculturality is seen as a process that displays all cultures as diverse, which means they are different but equally important. What this implies for foreign language education is that interculturality takes place between two or more different people and not only between two different languages.

\section{Permanent Dialogue in Pedagogical Environments and Negotiation of Pedagogical Agendas}

The next group of intercultural practices includes permanent dialogue in pedagogical environments and negotiating pedagogical agendas, both of which require the act of listening. The listening act, according to Srader (2015), is effective when "it succeeded in fulfilling the threshold duty of calling the relationship into existence" (p. 100). In other words, permanent dialogue implies the recognition of the other, as well as being able to engage in dialogue and mutual learning. Permanent dialogue helps subjects become aware of their differences, their relationship with others, and their own histories. Interculturality, in this sense, does not dismiss cultures. Instead, from its historicity, interculturality always reconfigures its conveyed forms.

When we accomplish an effective listening act, we, as teachers, can question the pressure to dehumanize and industrialize education. Education deals with human beings and subjectivities that cannot be homogenized and standardized. Thus, curricula must be based on principles that promote humanism and the capacity to appreciate otherness.

According to Aguirre and Ramos (2011), the Colombian classroom "is a mixture of students in the classrooms coming from different backgrounds, socioeconomic statuses, ethnicities and religious beliefs" (Aguirre \& Ramos, 2011, p. 170). In this sense, the concept of particularity (Kumaravadivelu, 2003) comes into play. Particularity relates to the need for a pedagogy that is both relevant, sensitive, and negotiated with a particular group. Moreover, particularity would include teachers and learners pursuing specific goals in a

98 particular institutional context embedded in a unique sociocultural milieu. Being part of a particular context means that the community develops specific social skills to participate in that context.

\section{Relationships with Territories, Traditional Lands, and Nature}

The next group of intercultural practices known as relationships with territories, traditional lands, and nature can deal with the very nature of students' contexts. For 
example, a school's pedagogical projects are a great opportunity to learn about what is important for a specific community. Pedagogical projects in rural institutions can address issues related to agriculture, cattle, and ancestral farming practices. Meanwhile, urban institutions can promote pedagogical projects that look at inner city infrastructure, traffic, and public education.

The relationships with Territories would not be possible without the active participation of teachers and the community. Ramos and Aguirre (2016) stressed the need for teachers to be part of the community they work in/with. The authors suggested that "Teachers must be introduced to the community's relevant ethnographic information in order to smoothly enter into the community, avoiding conflicts that could arise by not having cultural information about the group in question" (Ramos \& Aguirre, 2016, p. 215). Researchers like Moll and González (2004) have demonstrated the benefits of getting to know familiar contexts well and then building connections with families and communities. In fact, Brought, Bergmann, and Holt (2006) stated that students feel accepted when their families and communities are connected with the school. Once teachers get to know the community, they can negotiate classroom planning. It is crucial for teachers to comprehend the students' and community's cultural expectations, so that the students feel that the academic programs are pertinent to them.

Thus, in this sense of intercultural practice, teachers should not work alone. Teachers should work together and create environments to foster humanity and human relationships. In turn, this will allow the community to follow through with proposals which can transform their context.

\section{Ecology of Knowledges}

The final intercultural practice, ecology of knowledges, means learning and using students' identities and knowledges in the curriculum, as well as respecting students' families and communities. As educators, we cannot deny that students have experiences that are relevant to the learning process. Students and their communities share memories, religions, feelings, languages, and cultures that give them a unique voice. The recognition of such voices in classroom discourses is not enough to deeply understand the human being's complexities. Rather, recognition must encompass a deep comprehension of experiences and the incorporation of knowledges in the classroom. In Hooks' (1994) words, this concept of recognition agrees with Transgressive Pedagogies, which acknowledge the voice of all the social actors in the educative context. It is my belief that if students' voices are heard, the educative context affirms who students are. Students, in turn, are able to recognize their capacities so that they can develop autonomy. 


\section{Undertaking the Complexities of Interculturality}

My comprehension of interculturality has been shaped and reshaped by and with diverse social actors from different academic communities. I have had the opportunity to take part in studies and research articles that have considered interculturality as a possibility to echo other voices. All these teachers and researchers feel the pressure that comes with inequality and standardization in their contexts. The following research reports account for the authors' humility, readiness to learn, and openness to recognize and value diversity in education.

In terms of echoing the voice of women through narratives, we acknowledge Rallon and Peñaloza-Rallon (2021); Ramos-Holguín and Peñaloza-Rallón (2020); Vásquez-Guarnizo, Chía-Rios, and Tobar-Gómez (2020); Peñaloza-Rallón (2019); and Barbosa (2018). These authors have found significant links between gender, beliefs, and academic success or failure. These researchers have also spent time thinking about their own identities and how they play a vital role in their work with their students.

In another review of interculturality and research, we find that rurality is a key concept that ties in with learning about Territories and the people who inhabit them, as seen in the works of Ramos, Aguirre, and Pita (2021); Ramos, Aguirre, and Torres (2018); and Ramos, Aguirre, and Torres (2016). Most of these studies conclude that there is still a need to learn from the diversity of Territories, as they are connected to specific cultural practices that shape students' beliefs. The previous authors also emphasized the need to provide a more integrative and balanced view of the term rurality.

The exploration of identities is another area that has dealt with the comprehensive understanding of interculturality. Cuervo (2020); Ramos and Torres (2019); Ramos, Aguirre, and Torres (2018); Fajardo (2018); Pita (2019); Triana (2019) and Vasquez (2019) have worked on situated research studies in which participants' voices and identities are acknowledged. These researchers suggested that some of the issues that teachers encounter when working with students of diverse backgrounds may begin with their own lack of experience with diversity.

\section{Conclusions}

Having looked at interculturality as part of a human being's life and the possibilities of understanding the complexities of interculturality in ELT through intercultural practice, I wish to focus on a few final remarks for English language teacher educators in the Colombian context. 
Perhaps the only way to understand the process students are going through is to have gone through the process oneself. If one wants to comprehend students' realities, one needs to walk their path or, at least, to listen to their voices carefully.

As educators, it is our responsibility to expand our notion of diversity. In any classroom, students are diverse in terms of their social class, abilities, sexual orientation, etc. Thus, the course content should reflect who the participants are. Educators should address their students' milieu (cultural and socioeconomic realities) and view it as a rich resource for the curriculum. This means that content should be derived from the students' diversity and be included in the classroom.

In other words, students need to be treated and acknowledged as subjects not as objects. As teachers, we are called upon to fight against the coloniality of knowledge, which prioritizes Euro-American knowledges. Meanwhile, other kinds of knowledges, such as indigenous and farmers' knowledges have been vanished. It is our responsibility to become involved in "ways of knowing which are alternative to occidental hegemony" (Alvarado, 2015, p. 110).

In the case of foreign language programs, cultural symbols, language rules, and norms are reproduced. Likewise, social relations are accepted as natural, normal, unquestioned, and correct. As it is, these practices can be considered as a passive, accepted logic of domination. Nevertheless, a deep analysis of the implications of culture can be an alternative form of knowledge, which moves us away from hegemonic forms of control.

Thus, if we are to take into account the intercultural dimension, curricula cannot be the same in each country, city, or even grade level. Materials need to be culture specific. Despite the challenges in implementing the previous, I also see an array of opportunities for foreign language teaching programs, such as becoming involved with the community in the teaching/learning process, selecting teaching materials that are negotiated with the academic community, and accounting for the particularities of the context. This might help us overcome the coloniality of being that, according to Ramos and Peñaloza-Rallón (2020),

is focused on the distinction between superior and inferior human beings based on their race. Certain groups of people can be considered objects, or they can constitute the invalidity of existence. In other words, they can be invisible or naturalized as objects or sub-humans. (p. 20)

Finally, some questions we can ask ourselves as intercultural beings/teachers are: Are we considering what students already know from home, community, and school? Do we understand local communities and links? Do we talk to students, parents or family members, and community members? Do we plan community-based learning activities? Do we provide opportunities for parents or families to participate in classroom activities? Do we draw on students' "funds of knowledge" (Moll \& González, 2004)? Do we support collaborative work among parents, communities, and schools in shaping educational programs together? 
Do we foster shared experiences that recognize diversity? Do we invite community members to share expertise related to the topic of the class? Do we make connections with students' lives out of school? Do we interact in ways that respect students' cultural norms that may be different from the teacher's, such as wait time, eye contact, and turn taking? Do we provide opportunities for students to interact with one another? Do we deeply comprehend our students' realities? Do we avoid superficial cultural understandings? Are we sympathetic to our students' realities? Do we feel free to see, listen, touch, and be touched by others?

Clearly, the path to teach from an intercultural perspective is a long one for both preservice and in-service teaching programs. Incorporating interculturality in teacher education programs will greatly depend on the students, their life experiences, and the teacher-educators that they will encounter along the way.

\section{References}

Aguirre, J., \& Ramos, B. (2011). Fostering skills to enhance critical educators: A pedagogical proposal for pre-service teachers. HOW, 18, 169-197.

Alban, A. (2008). “¿Interculturalidad sin decolonialidad? Colonialidades circulantes y prácticas de re-existencia” In A. Grueso Bonilla \& W. Villa (Eds.), Diversidad, interculturalidad y construcción de ciudad (pp. 64-96). Universidad Pedagógica Nacional.

Barbosa, A. (2018). Stories to wake up: Women narratives reconstructing themselves as sociobistorical subjects. [Unpublished master's thesis]. Universidad Pedagógica y Tecnológica de Colombia.

Besalú, X. (2002). Diversidad cultural y educación. Síntesis.

Brought, J., Bergmann, Sh., \& Holt, L. (2006). Teach me and I dare you!! Richard Adin Editorial Services.

Cruz, E. (2013). Multiculturalismo e interculturalismo: Una lectura comparada. Cuadernos Interculturales, $11(20)$, 45-76.

Cuervo, J. (2020). Resistance against homogenization practices. [Unpublished master's thesis]. Universidad Pedagógica y Tecnológica de Colombia.

De Sousa Santos, B. (2010). Para descolonizar Occidente. Más allá del pensamiento abismal. Clacso.

102 Fajardo, N. (2018). English foreign language teachers' voices revealing their teaching experiences with inclusive education. [Unpublished master's thesis]. Universidad Pedagógica y Tecnológica de Colombia.

Granados-Beltrán, C. (2016). Critical interculturality. A path for pre-service ELT teachers. Íkala 21(2), 171-187.

Hooks, B. (1994). Teaching to transgress. Routledge.

Kumaravadivelu, B. (2003). Beyond methods: Macrostrategies for language teaching. Yale University Press. 
Maldonado-Torres, N. (2007). "Sobre la colonialidad del ser: Contribuciones al desarrollo de un concepto”. In S. Castro-Gómez \& R. Grosfoguel (Eds.). El giro decolonial. Reflexiones para una diversidad epistémica más allá del capitalismo global (pp. 127-167). Siglo del Hombre.

Mazurek, R. (2015). Andar no Território: Intercambios locais para conbecer, valorizar e proteger o seu lugar. Technical Report Instituto de Pesquisa e Formacao Indígena- Iepé.

Moll, L., \& González, N. (2004). Engaging life: A funds-of-knowledge approach to multicultural education. In J. Banks (Ed.), Handbook of research on multicultural education (pp. 699-715). JosseyBass.

Nieto, S. (2013). Finding joy in teaching students of diverse backgrounds. Heinemann.

Peñaloza, A. (2019). Gender and academic writing. [Unpublished master's thesis]. Universidad Pedagógica y Tecnológica de Colombia.

Peñaloza, A. (2020). Leadership, risk taking, and social gender roles among Colombian female undergraduate language learners. Profile: Issues in Teachers' Professional Development, 22(2), 33-47. https://doi.org/10.15446/profile.v22n2.82535

Pita, A. (2019). Unveiling eleventh graders' self-image construction through their life stories. [Unpublished master's thesis]. Universidad Pedagógica y Tecnológica de Colombia.

Rallón, A. O., \& Peñaloza-Rallón, A. C. (2021). Write On, Women! Discovering Personal Skills through Feminist Pedagogy and Narratives. HOW, 28(1), 163-182. https://doi.org/10.19183/ how.28.1.567

Ramos, B. (2019). Los sentidos de la formación de educadores en Idiomas Modernos en la Universidad Pedagógica y Tecnológica de Colombia. Editorial Uptc.

Ramos-Holguín, B., \& Peñaloza, A. C. (2019). Editorial. Enletawa Journal, 12(2), 8-9.

Ramos, B., \& Aguirre, J. (2016). English language teaching in rural areas: A new challenge for English language teachers in Colombia. Cuadernos de Lingüística Hispánica, 27, 209- 222.

Ramos, B., \& Torres, N. (2019). Becoming language teachers: Exploring student-teachers' identities construction through narratives. Learning Research Journal GiST, 18, January-June, 6-27.

Ramos, B., Aguirre, J., \& Pita, A. (2021). Understanding the complexities of self-image in a rural setting. Editorial Uptc.

Ramos, B., Aguirre, J., \& Torres, N. (2016). Trabajando colaborativamente en la enseñanza de inglés como lengua extranjera: Una experiencia con profesores de primaria en un contexto rural. Aptis for Teachers Action Research Awards.

Ramos, B., Aguirre, J., \& Torres, N. (2018). Student-teachers' identity construction and its connection with student-centered approaches. A narrative study. Editorial Uptc.

Ramos, B., Aguirre, J., \& Torres, N. (2018a). Enhancing EFL speaking in rural settings: Challenges and opportunities for material developers. Editorial UPTC. 
Ramos-Holguín, B., \& Peñaloza-Rallón, A. (2020). Central events and causal connections: A narrative-inquiry study among Colombian female scholars in their processes as writers. Learning Research Journal GiST, 20, January-June, 33-65.

Rodríguez, A., Aristizábal, M., Albán, A., López, C., Lozada, L., Guzmán, A. \& Gaviria, Y. (2016). Experiencias interculturales para la convivencia escolar. Editorial Universidad del Cauca.

Srader, D. (2015) Performative listening. International Journal of Listening, 29(2), 95-102, DOI: 10.1080/10904018.2014.892834

Triana, Y. (2019). Unveiling eleventh graders' cultural diversity awareness through their discourses. [Unpublished master's thesis]. Universidad Pedagógica y Tecnológica de Colombia.

Vásquez, J. (2019). Pre-service teachers' decision making processes in their pedagogical practice: A narrative study. [Unpublished master's thesis]. Universidad Pedagógica y Tecnológica de Colombia.

Vásquez-Guarnizo, J., Chía, M., \& Tobar, M. (2020). EFL Students’ perceptions on gender stereotypes through their narratives. Learning Research Journal GiST, 21, July-December, 141-166.

Walsh, C. (2009). Interculturalidad crítica e pedagogía de-colonial: In-surgir, re-existir y re-vivir. In V. M. Candau (Ed.), Educação intercultural na América Latina: Entre concep̣cões, tensões e propostas (pp. 14-53). 7 Letras. 